nhân $(3,9 \%)$ xuất hiện giảm bạch cầu trung tính độ 3 và giảm huyết sắc tố độ 2 phải trì hoãn điều trị 1 tuần, 1 bệnh nhân $(2 \%)$ giảm bạch cầu trung tính độ 4 và giảm huyết sắc tố độ 2 ngưng điêu trị sau 3 chu kỳ, 1 bệnh nhân ( $2 \%$ ) giảm bạch cầu trung tínhđộ 3 và giảm tiểu cầu độ 2 ngưng điêu trị sau 4 chu kỳ.

Tỳ lệ trì hoãn điều trị do độc tính tăng AST/ALT là $2 \%$, thần kinh cảm giác ngoại vi là $2 \%$, đau xương khớp là $2 \%$. Các bệnh nhẩn điều phải trì hoãn 1-2 tuần điều trị. Trong nghiên cứu của chúng tôi không ghi nhận trường hợp nào tử vong liên quan đến độc tính.

\section{KẾT LUẬN}

Các độc tính trên hê tạo huyết bao gồm: tỷ lệ giảm $\mathrm{BC}, \mathrm{BCTT}$ là $25,5 \% ; 37,3 \%$, trong đó chủ yếu là giảm $B C$ và giảm $B C T$ độ $1 / 2$ là $19,6 \%$ và $27,4 \%$. Tỷ lệ giảm HST, giảm tiểu câu là $29,4 \%$ và $13,7 \%$, đều ở độ $1 / 2$. Độc tính trên gan, thận, tiêu hóa bao gồm: tỷ lệ tăng AST/ALT và tăng Creatinin là $13,7 \%$ và $2,0 \%$, tỷ lệbuồn nôn, nôn là $19,6 \%$ và $9,8 \%$, tiêu chảy là $11,8 \%$, đều ở độ $1 / 2$. Tỷ lệ rối loạn thần kinh cảm giác ngoaai vi, đau xương khớp là $17,6 \%$ và $21,6 \%$, ở độ $1 / 2$. Rụng tóc gặp ở tất cả các bệnh nhân sau hóa trị. Tỷ lệ trì hoã̃n và ngưng điều trị thấp, chủ yếu do giảm $B C T T$ là $7,8 \%$ và giảm HST là $5,9 \%$. Không có trường hợp nào tử vong liên quan đến độc tính. Các độc tính ghi nhận trong nghiên cứu đều chấp nhận được và an toàn để điêu trị cho bệnh nhân cao tuổi.

\section{TÀI LIẸU THAM KHẢO}

\section{Lê Tuấn Anh, Nguyễn Ngọc Bảo Hoàng} (2013). Đặc điểm lâm sàng và điều trị của 1158 bệnh ñhân ung thư phổi tại Trung tâm Ung bướu Chợ Rẫ̂y. Y học thực hành, 8(8), 7869.

2. Nguyến Trọng Hiếu (2012), Đánh giá hiệu quả và độc tính phác đồ Paclitaxelnano/Carboplatin trong ung thư phổi không tế bào nhỏ giai đoạn IIB-IV, Luận văn thạc sỹ y học, Đại học Y Hà Nội.

3. Trương Thi Kiêu Oanh (2017), Đánh giá đáp ứng hóa chẩt phác đồ Paclitaxel-Carboplatin bước 1 ở bệnh nhân ung thư phổi không tế bào nhỏ giai đoạn IIIB-IV trên 60 tuổi, Luận án thạc sỹ y học, Đại học Y Hà Nội.

4. Bray F, Ferlay J et al (2018). Global cancer statistics 2018: GLOBOCAN estimates of incidence and mortality worldwide for 36 cancers in 185 countries, CA Cancer J Clin, 2018 Nov, 68(6), 394-424.

5. B. Biesma, A. N. M. Wymenga, A. Vincent et al (2011). Quality of life, geriatric assessment and survival in elderly patients with non-small-cell lung cancer treated with carboplatin-gemcitabine or carboplatin-paclitaxel: NVALT-3 a phase III study. Annals of Oncology, 22, 1520-1527.

6. Hala Mohamed El-Shenshawy, Saleh Taema, Eman El-Zahaf et al (2012). Advanced non-smal cell lung cancer in elderly patients : The standard every 3-weeks versus weekly paclitaxel with carboplatin. Egyptian Journal of Chest Diseases and Tuberculosis, 61, $485-493$.

7. Junya Zhu, Dhruv B. Sharma, Aileen B. Chen, et al(2013). Comparative Effectiveness of Three Platinum - Doublet Chemotherapy Regimens in Elderly Patients With Advanced Non-Small Cell Lung Cancer. Cancer, 119, 2048-2060.

\title{
NGHIÊN CỨU RỐI LOAN LIPID MÁU Ở NGƯờI CAO TUỔI TĂNG HUYẾT ÁP
}

\begin{abstract}
TÓM TẮT.
Mục tiêu: Khảo sát tỷ lệ rối loạn lipid máu và mối liên quan giữa rối loạn lipid máu với một số chỉ số lâm sàng, cận lâm sàng ở người cao tuổi tăng huyết áp điêu trị tại Bệnh viện đa khoa 115 - Nghệ An. Phương pháp nghiển cứu: Nghiên cứu mô tả cắt ngang được thực hiện trên 150 bệnh nhân tăng huyết áp nguyên phát điều trị tại Bệnh viện đa khoa 115 Nghệ An. Kết quả: (1) Tỵ lệ rối loạn lipid máu ở bênh nhân cao tuổi tăng huyết áp là 88,0\% \% (2) Có mối liêên quan giữa rối loạn lipid máu với tình trạng gan nhiễm
\end{abstract}

\footnotetext{
${ }^{1}$ Trường Đại họ Y khoa Vinh

Chịu trách nhiệm chính: Nguyễn Văn Tuấn

Email: tuanminh1975@gmail.com

Ngày nhận bài: 9.8.2021

Ngày phản biện khoa học: 5.10.2021

Ngày duyệt bài: 13.10.2021
}

\section{Nguyễn Văn Tuấn ${ }^{1}$, Hoàng Thị Cúc ${ }^{1}$}

mõ, chỉ số BMI, chỉ số vòng bụng, thời gian phát hiện tăng huyết áp, uống nhiêuu rượu và ít vận động thể lực; (3) Chưa thấy mối liên quan giữa rối loạn lipid máu với nhóm tuổi (nhóm bệnh nhân $\geq 70$ tuổi so với nhóm bệnh nhân 60 - 69 tuổi), giới, tiền sử gia đình bị rối loạn lipid máu. Kết luận: Rối loạn lipid máu chiếm tỷ lệ rất cao ở bệnh nhân cao tuổi tăng huyết áp, đặc biệt ở những bệnh nhân có các yếu tố nguy cơ tim mạch khác đi kèm như thừa cân, béo phì, uống nhiều rượu và ít vận động thể lực.

Tư khóa: Rối loạn lipid máu, người cao tuổi, tăng huyết áp

\section{SUMMARY \\ DYSLIPIDEMIA IN ELDERLY PATIENTS WITH HYPERTENSION}

Objectives: To survey the prevalence of dyslipidemia and the relationship between dyslipidemia and some clinical and subclinical indexs 
among the elderly patients with hypertension who were treated at 115 General Hospital - Nghe An. Methods: This was a cross-sectional study conducted on 150 the ederly patients with hypertension who were treated at 115 General Hospital - Nghe An. Results: (1) The prevalence of dyslipidemia among the elderly with hypertension was $88,0 \%$; (2) There is the relation between dyslipidemia with: fatty liver status, BMI, waist circumference, duration of hypertension, alcohol abuse and physical inactivity; (3) No relationship has been found between dyslipidemia with: age group ( $\geq 70$ years old compared to $60-69$ years old), sex, family history of dyslipidemia. Conclusion: Dyslipidemia account for a very high proportion among the elderly patients with hypertension, especially in patients with other associated cardiovascular risk factors such as overweight, obesity, alcohol abuse and physical inactivity.

Keywords: Dyslipidemia, the elderly, hypertension

\section{I. ĐẶT VẤN ĐỀ}

Rối loạn lipid (RLLP) máu và tăng huyết áp (THA) là 2 yếu tố nguy cơ độc lập đối với tổn thương tim mạch. Tồng hợp cả hai yếu tố trên đã được chứng minh làm tăng nguy cơ tim mạch theo cấp số nhân hơn là tổng nguy cơ đơn lẻ [2]. Tỷ lệ người bị tăng huyết áp ngày càng gia tăng ở Việt nam nói chung và ở Nghệ An nói riêng. Rối loạn lipid máu đóng một vai trò quan trọng trong rối loạn chức năng nội mô và là trung tâm của quá trình xơ vữa động mạch, huyết khối, đề kháng insulin và tăng huyết áp [2]. Mối liên quan giữa tăng huyết áp với nguy cơ đột quy và bệnh mạch vành đã được thiết lập rõ ràng. Tương tự, cũng có mối liên quan chặt chẽ giữa rối loạn lipid máu với bệnh mạch vành. Nhiều nghiên cứu đã chỉ ra tăng huyết áp và rối loạn lipid máu thường cùng tồn tại trên một bệnh nhân và làm tăng cao nguy cơ tổn thương tim mạch và đột quy. [5]. Phát hiện sớm các rối loạn lipid sẽ giúp áp dụng các phương thức điều trị thích hợp như thực hiện các biện pháp thay đổi lối sống có hại cho sức khỏe tim mạch. Việc xác định đặc điểm rối loạn lipid máu ở người cao tuổi tăng huyết áp là cơ sở để xử trí trí thành công các nguy cơ tim mạch trên đối tượng này. Rối loạn lipid máu ở người tăng huyết áp cũng đã được chứng minh là thay đổi tùy theo đặc điểm dân tộc, kinh tế xã hội và văn hóa của từng vùng [3]. Ở Nghệ An hiện nay chưa có nghiên cứu nào được báo cáo về tình trạng rối loạn lipid máu ở bệnh nhân cao tuổi tăng huyết áp.

Xuất phát từ những lý do trên, để tìm hiểu đặc điểm rối loạn lipid máu ở bệnh nhân cao tuổi tăng huyết áp, chúng tôi nghiển cứu đề tài với mục tiêu: Khảo sát tỷ lệ rối loạn lipid máu và mối liên quan giữa rối loạn lipid máu với một số chỉ số lâm sàng, cận lâm sàng ở người cao tuổi tăng huyết áp điều trị tại Bệnh viện đa khoa 115 - Nghệ An.

\section{II. ĐỐI TƯỢNG VÀ PHƯƠ'NG PHÁP NGHIÊN CỨU 2.1. Đối tượng nghiên cứu}

2.1.1. Tiêu chuấn lựa chon đối tượng nghiên cứu. Bệnh nhân từ 60 tuổi trở lên được chẩn đoán xác định là THA nguyên phát.

\subsubsection{Tiêu chuẩn loại trư}

+ Bệnh nhân mắc các bệnh lý có ảnh hưởng đến lipid máu như: cường giáp, suy giáp, suy tim nặng, xơ gan, bệnh thận mạn.

+ Bệnh nhân không đồng ý tham gia nghiên cứu.

\subsection{Phương pháp nghiên cứu.}

2.2.1. Thiết kế nghiên cứu: Nghiên cứu mô tả cắt ngang có phân tích

2.2.2. Cỡ mẫu: 150 bệnh nhân

2.2.3. Thời gian và địa điểm nghiên cứu:

- Thời gian nghiên cứu: Từ tháng 01/2020 đến tháng 05/2020.

- Địa điểm nghiên cứu: Phòng khám ngoại trú THA, Bệnh viện Đa Khoa 115 Nghệ An.

\subsubsection{Các kỹ thuật và phương tiện được} sử dụng trong nghiên cứu

- Đo huyết áp: Đo huyết áp bằng máy đo huyết áp đồng hồ ALP K2 500V FT801 của hãng ALPK2 theo đúng quy trình kỹ thuật của Bộ $Y$ tế 2010.

- Xét nghiệm bilan Lipid máu: Lấy máu vào buổi sáng khi chưa ăn (khi đói). Các chỉ số lipid máu được tiến hành xét nghiệm trên máy sinh hóa tự động AU480 do hãng Beckman coulter do Mỹ sản xuất năm 2016.

- Ghi Điện tâm đồ: Được thực hiện trên máy điện tim 3 cần Nihon kohden cardiofax $S$ do hãng Nihon kohden sản xuất năm 2013.

- Siêu âm gan để đánh giá tình trạng gan nhiễm mõ̃: Được thực hiện trên máy siêu âm GE Voluson S6 do hãng Voluson sản xuất năm 2017.

\subsubsection{Các tiêu chuẩn áp dụng trong} nghiên cứu

2.2.4.1. Tiêu chuẩn chẩn đoán tăng huyết áp

Chẩn đoán tăng huyết áp dựa vào "Khuyến cáo về chẩn đoán và điêu trị tăng huyết áp 2008" của Hội Tim mạch Quốc gia Việt Nam.

\begin{tabular}{|c|c|c|c|}
\hline & $\begin{array}{c}\text { Huyêt áp } \\
\text { tâm thu } \\
(\mathrm{mmHg})\end{array}$ & $\begin{array}{c}\text { Huyết áp } \\
\text { tâm } \\
\text { trương } \\
(\mathrm{mmHg})\end{array}$ \\
\hline Tối ưu & $<120$ & và & $<80$ \\
\hline Bình thường** & $120-129$ & và/hoặc & $80-84$ \\
\hline
\end{tabular}




\begin{tabular}{|c|c|c|c|}
\hline $\begin{array}{c}\text { Bình thường } \\
\text { cao** }\end{array}$ & $130-139$ & và/hoặc & $85-89$ \\
\hline THA độ 1 & $140-159$ & và/hoặc & $90-99$ \\
\hline THA độ 2 & $160-179$ & và/hoặc & $100-109$ \\
\hline THA độ 3 & $\geq 180$ & và/hoặc & $\geq 110$ \\
\hline $\begin{array}{c}\text { THA Tâm Thu } \\
\text { đơn độc }\end{array}$ & $\geq 140$ & và & $<90$ \\
\hline
\end{tabular}

2.2.4.2. Tiêu chuẩn chẩn đoán rối loạn lipid máu. Chẩn đoán rối loạn lipid máu theo hướng dẫn chẩn đoán và điều trị Bệnh nội tiết chuyển hóa (Ban hành kèm theo Quyết định số 3879/QĐ-BYT ngày 30 tháng 09 năm 2014 của Bộ trưởng Bộ Y tế) [1]. Chẩn đoán xác định rối loạn lipid máu khi có một hoặc nhiêu rối loạn sau:

- Cholesterol máu > 5,2 mmol/L (200mg/dL).

- Triglycerid $>1,7 \mathrm{mmol} / \mathrm{L}(150 \mathrm{mg} / \mathrm{dL})$.

- LDL-cholesterol > 2,58mmol/L (100mg/dL).

- HDL-cholesterol < 1,03mmol/L ( $40 \mathrm{mmol} / \mathrm{L})$.

2.2.4.3. Tiêu chuẩn chẩn đoán gan nhiếm mõ̃ trên siêu âm

Chẩn đoán gan nhiễm mõ bằng phương pháp siêu âm theo khuyến cáo của Hội tiêu hóa Hoa kỳ [9], tiêu chuẩn siêu âm của gan nhiễm mõ bao gôm:

- Gan tăng sáng, mịn và đồng nhất.

- Gan tăng âm so với thận.

- Mờ các cấu trúc mạch máu.

- Giảm độ xuyên sâu của chùm tia siêu âm.

2.2.4.4. Tiêu chuẩn đánh giá một số chỉ số nhân trắc

* Chỉ số BMI (theo phân loại Hiệp hội Đái tháo đường các nước Đông Nam Á): Cân nặng (kg)

$$
\operatorname{BMI}\left(\mathrm{kg} / \mathrm{m}^{2}\right)=
$$

$$
\text { (Chiều cao) }{ }^{2}\left(\mathrm{~m}^{2}\right)
$$

Nhân định kêt quả:

Thấp cân: BMI < 18,5

Thừa cân: BMI từ $23-24,9$

Bình thường: BMI từ 18,5 - 22,9

Béo phì độ IBMI từ $25-29,9$

Béo phì độ II: BMI $\geq 30$.

*Chỉ số vòng bụng: Béo bunng được xác định khi vòng bụng $\geq 90 \mathrm{~cm}$ đối với nam và $\geq 80 \mathrm{~cm}$ đối với nữ.

\subsubsection{Các tiêu chuẩn khác áp dụng} trong nghiên cứu

- Người có lối sống ít vận động: không thực hiện các bài tập thể dục thông thường, đi bộ < 30 phút/ngày.

- Người lạm dụng rượu: là người thường xuyên uống rượu khi uống trung bình trên 2 chén (khoảng $30 \mathrm{ml}$ rượu mạnh hoặc $720 \mathrm{ml}$ bia) mỗi ngày trong thời gian trên 2 năm.
- Tiền sử gia đình có rối loạn lipid máu: Bố, mẹ, anh chị em ruột có tiền sử hoặc hiện tại bị rối loạn lipid máu.

2.3. Xử lý số liệu: - Số liệu được xử lý bằng phần mềm SPSS 20.0.

- Sử dụng test X2 để so sánh sự khác biệt về tỷ lệ phần trăm.

- Sự khác biệt có ý nghĩa thống kê khi p < 0,05.

\section{KẾT QUẢ NGHIÊN CỨU}

3.1. Tỷ lệ và đặc điểm RLLP máu ở người cao tuổi THA của đối tượng nghiên cứu

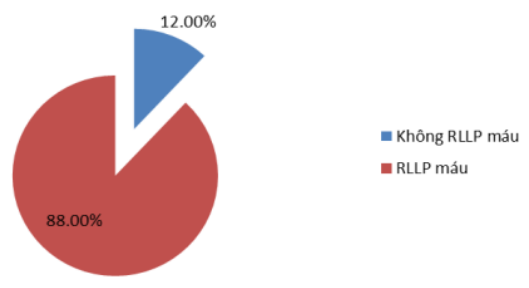

Biểu đồ 1: Tỷ lệ bệnh nhân có RLLP máu của đôi tướng nghiên cứu

Nhận xét: $88,00 \%$ bênh nhân THA nguyên phát ở người cao tuổi có rối loạn lipid máu.

Bảng 1: Tỷ lệ RLLP máu theo giới tính của đôî tượng nghiên cứu

\begin{tabular}{|c|c|c|c|c|}
\hline \multirow{2}{*}{ Giới tính } & \multicolumn{4}{|c|}{ RLLP máu } \\
\cline { 2 - 5 } & \multicolumn{3}{|c|}{ Có } & \multicolumn{1}{c|}{ Không } \\
\cline { 2 - 5 } & $\mathbf{n}$ & $\mathbf{\%}$ & $\mathbf{n}$ & $\mathbf{\%}$ \\
\hline Nam & 58 & 85,29 & 10 & 14,71 \\
\hline Nữ & 74 & 90,24 & 8 & 9,76 \\
\hline p & \multicolumn{4}{|c|}{0,353} \\
\hline
\end{tabular}

Nhânn xét: Tỷ lệ rối loạn lipid máu của nam giới là $85,29 \%$ và của nữ giới là $90,24 \%$, sự khác biệt không có ý nghĩa thống kê $(p>0,05)$

Bảng 2: Tỷ lể bênh nhân RLLPM theo

\begin{tabular}{|c|c|c|c|c|}
\hline \multirow{3}{*}{ Nhóm tuổi } & \multicolumn{4}{|c|}{ RLLP máu } \\
\hline & \multicolumn{2}{|c|}{ Có } & \multicolumn{2}{|c|}{ Không } \\
\hline & $\mathrm{n}$ & $\%$ & $n$ & $\%$ \\
\hline$\geq 70$ & 49 & 89,09 & 6 & 10,91 \\
\hline $60-69$ & 83 & 87,37 & 12 & 12,63 \\
\hline$p$ & \multicolumn{4}{|c|}{0,754} \\
\hline
\end{tabular}
nhóm tuổi của đồi tượng nghiên cứu

Nhận xét: Tỷ lệ rối loạn lipid máu của nhóm tuổi 60-69 là 87,37\%, của nhóm tuổi $\geq 70$ là $89,09 \%$. Sự khác biệt không có ý nghĩa thống kê với $p>0,05$.

Bảng 3: Tỷ lê bệnh nhân có RLLP máu ở nhóm gan nhiếm mõ̃ so với nhóm không bi gan nhiếm mõ trên siêu âm của đối tượng nghiên cứu

\begin{tabular}{|l|l|l|}
\hline \multirow{2}{*}{ Siêu âm gan } & \multicolumn{2}{|c|}{ RLLP máu } \\
\cline { 2 - 3 } & Có & Không \\
\hline
\end{tabular}




\begin{tabular}{|c|c|c|c|c|}
\hline & $\mathbf{n}$ & $\mathbf{\%}$ & $\mathbf{n}$ & $\mathbf{\%}$ \\
\hline Gan nhiêm mõ & 85 & 92,39 & 7 & 7,61 \\
\hline $\begin{array}{c}\text { Gan không } \\
\text { nhiếm mõ }\end{array}$ & 47 & 81,03 & 11 & 18,97 \\
\hline p & \multicolumn{4}{|c|}{0,037} \\
\hline
\end{tabular}

Nhận xét: Nhóm bệnh nhân gan nhiễm mõ có tỷ lệ RLLP máu là $92,39 \%$ cao hơn nhóm bênh nhân không có gan nhiễm mõ là $81,03 \%$. Sự khác biệt có ý nghĩa thống kê với $p=0,037$.

3.2. Một số yếu tố liên quan đến RLLP máu ở bệnh nhân cao tuổi THA của đối tượng nghiên cứu

Bảng 4: Môi liên quan giữa RLLP máu với chỉ số BMI, vòng bụng của đôii tượng nghiên cứu

\begin{tabular}{|c|c|c|c|c|c|}
\hline \multirow{3}{*}{\multicolumn{2}{|c|}{ Chỉ số nhân trắc }} & \multicolumn{4}{|c|}{ RLLP máu } \\
\hline & & \multicolumn{2}{|c|}{ Có } & \multicolumn{2}{|c|}{ Không } \\
\hline & & $\mathbf{n}$ & $\%$ & $\mathbf{n}$ & $\%$ \\
\hline \multirow{2}{*}{$\begin{array}{c}\text { BMI } \\
\left(\mathbf{k g} / \mathbf{m}^{2}\right)\end{array}$} & $<23$ & 52 & 81,25 & 12 & 18,75 \\
\hline & $\geq 23$ & 80 & 93,02 & 6 & 6,98 \\
\hline \multicolumn{2}{|r|}{$\mathrm{p}$} & \multicolumn{4}{|c|}{0,028} \\
\hline \multirow{2}{*}{ Vòng bụng } & Không béo bụng & 48 & 81,35 & 11 & 18,65 \\
\hline & Béo bụng & 84 & 92,31 & 7 & 7,79 \\
\hline & $\mathrm{p}$ & \multicolumn{4}{|c|}{0,044} \\
\hline
\end{tabular}

Nhân xét: Tình trạng rối loạn lipid máu có liên quan đến chỉ số BMI và vòng bụng của bệnh nhân cao tuổi THA $(\mathrm{p}<0,05)$.

Bảng 5: Tý lệ RLLP máu theo thời gian phát hiện THA của đôí tượng nghiên cứu

\begin{tabular}{|c|c|c|c|c|c|c|c|}
\hline \multirow{2}{*}{$\begin{array}{l}\text { RLLP máu } \\
\text { Thời gian THA }\end{array}$} & \multicolumn{2}{|c|}{ Có } & \multicolumn{2}{|c|}{ Không } & \multirow[b]{2}{*}{$\mathbf{p}$} & \multirow{2}{*}{ OR } & \multirow{2}{*}{$95 \%$ CI } \\
\hline & $\mathbf{n}$ & $\%$ & $\mathbf{n}$ & $\%$ & & & \\
\hline$\geq 5$ năm & 72 & 91,14 & 5 & 8,86 & 0.033 & 3,120 & $1,052-9,250$ \\
\hline$<5$ năm & 60 & 82,19 & 13 & 17,81 & 0,033 & $3,1 \angle 0$ & $1,05<-9,<30$ \\
\hline
\end{tabular}

Nhận xét: Thời gian bị THA có liên quan đền sự xuất hiện rối loạn lipid máu ở bệnh nhân cao tuối THA $(\mathrm{p}<0,05)$.

Bảng 6: Môi liên quan giữa RLLP máu với tiền sử gia đình mắc RLLP máu của đôi tượng nghiên cứu

\begin{tabular}{|c|c|c|c|c|}
\hline \multirow{2}{*}{$\begin{array}{c}\text { Tiền sử gia đình RLLP } \\
\text { máu }\end{array}$} & \multicolumn{4}{|c|}{ RLLP máu } \\
\cline { 2 - 5 } & $\mathbf{n}$ & $\mathbf{\%}$ & $\mathbf{n}$ & $\mathbf{\%}$ \\
\hline Có & 36 & 81,82 & 8 & 18,18 \\
\hline Không & 96 & 90,57 & 10 & 9,43 \\
\hline$p$ & \multicolumn{3}{|c|}{0,133} \\
\hline
\end{tabular}

Nhận xét: Chưa nhận thấy mối liên quan giữa rối loạn lipid máu với tiền sử gia đình bị rối loạn lipid máu $(p>0,05)$.

Bảng 7: Mối liên quan giữa RLLP máu với lối sống của đôi tượng nghiên cứu

\begin{tabular}{|c|c|c|c|c|c|c|c|c|}
\hline \multirow{2}{*}{\multicolumn{2}{|c|}{ Yếu tố lối sống }} & \multicolumn{2}{|c|}{ Có } & \multicolumn{2}{|c|}{ Không } & \multirow[b]{2}{*}{$\mathbf{p}$} & \multirow{2}{*}{ OR } & \multirow{2}{*}{$95 \%$ CI } \\
\hline & & $\mathrm{n}$ & $\%$ & $\mathbf{n}$ & $\%$ & & & \\
\hline Lạm dụng & Có & 75 & 93,75 & 5 & 6,25 & \multirow[b]{2}{*}{0,021} & \multirow[b]{2}{*}{3,4} & \multirow{2}{*}{$1,153-10,149$} \\
\hline rượu & Không & 57 & 81,43 & 13 & 18,57 & & & \\
\hline Lối sống ít & Có & 78 & 92,86 & 6 & 7,14 & \multirow{2}{*}{0,039} & \multirow{2}{*}{2,889} & \multirow{2}{*}{$1,022-8,170$} \\
\hline vận động & Không & 54 & 81,19 & 12 & 18,81 & & & \\
\hline
\end{tabular}

Nhận xét: Lam dụng rượu và lối sống ít vận động thể lực có liên quan đền sự xuất hiện rối loạn lipid máu ở người cao tuổi THA $(p<0,05)$.

\section{BÀN LUÂN}

4.1. Tỷ lệ và đặc điểm rối loạn lipid máu của đối tượng nghiên cứu. Thiết kế nghiên cứu của chúng tôi nhằm mục đính xác định tỷ lệ rối loạn lipid máu và các yếu tố liên quan đến rổi loạn lipid máu ở người cao tuổi tăng huyết áp điều trị ngoại trú tại bệnh viện đa khoa 115 Nghệ An. Kết quả nghiên cứu của chúng tôi cho thấy tỷ lệ rối loạn lipid máu ở bệnh nhân cao tuổi
THA là $88,0 \%$. Kết quả này cao hơn trong nghiên cứu của Nguyễn Thị Hồng Thủy (1016) trên bênh nhân cao tuổi THA tại Phú Yên. Nghiên cứu của Francesco Spannella và cộng sự (2019) trên 1219 bệnh nhân cao tuổi tăng huyết áp cho thây tỉ rối loạn lipid máu ở bệnh nhân tăng huyết áp là $91,1 \%$. Nghiên cứu của Ayoade O.G và cộng sự (2020) cho thấy tỷ lệ rối loạn lipid máu ở bệnh nhân tăng huyết áp là 60,0\% [2]. 
Trong nghiên cứu của chúng tôi nữ giới có tỷ lệ bị RLLP máu cao hơn nam giới $(90,24 \%$ so với 85,29\%), tuy nhiên sự khác biệt không có ý nghĩa thống kê. Điều này phù hợp với các nghiên cứu quy mô lớn như nghiên cứu Framingham và Điều tra về sức khỏe và dinh dưỡng Quốc gia Hoa Kỳ (NHANES). Nguyên nhân của sự khác nhau này là do sự suy giảm ảnh hưởng của hormon sinh dục gây ra sự khác biệt trong cân bằng nội môi lipid huyết tương giữa nam so với nữ [9].

Nghiên cứu của chúng tôi cũng cho thấy tỷ lệ RLLP máu ở nhóm bệnh nhân $\geq 70$ tuối là 89,09\% cao hơn nhóm bệnh nhân 60- 69 tuổi là $87,37 \%$, tuy nhiên sự khác biệt không có ý nghĩa thống kê với $p>0,05$. Trong nghiên cứu của Võ Như An, nhóm bệnh nhân dưới 70 tuổi tỷ lệ RLLP máu chiếm $49,6 \%$ và nhóm bệnh nhân trên 70 tuổi tỷ lệ này là $50,4 \%$ và sự khác biệt cũng không có ý nghĩa thống kê với $p=0,116$. Ngược lại, trong nghiên cứu của Urvi Sharma và cộng sự (2013) ở cộng đồng người Delhi cho thấy tuổi có liên quan đến tình trạng rối loạn lipid máu ở bệnh nhân tăng huyết áp [7]. Ericsson và cộng sự đưa ra giả thuyết rằng tăng lipid máu khi tuổi cao có thể do giảm quá trình dị hóa và thanh thải lipoprotein trong huyết tương [4].

Tỷ lệ gan nhiếm mõ trên siêu âm của đối tượng nghiên cứu trong nghiên cứu của chúng tôi là $61,3 \%$, trong đó nhóm bệnh nhân bị gan nhiễm mõ có tỷ lệ RLLP máu là $92,39 \%$ và nhóm bệnh nhân không bị gan nhiễm mõ̃ có tỷ lệ RRLP máu là $81,03 \%$, sự khác biệt này có ý nghĩa thống kê với $p=0,037$. Kết quả này nghiên cứu của Nguyễn Thị Hồng Thủy (2016) với tỷ lệ gan nhiễm mõ là $56,28 \%$, tỷ lệ gan nhiễm mõ có liên quan đến RLLP máu chiếm $63,84 \%$, tỷ lệ gan nhiễm mõ không có rối loạn lipid chiếm 30,38\%, sự khác biệt có ý nghĩa thống kê, $p<0,001$. Rối loạn lipid máu lâu dài có thể làm tăng biểu hiện và hoạt động của yếu tố điều hòa sterol gắn với protein-1c, một yếu tố phiên mã, ảnh hưởng xấu đến cấu trúc tổng hợp lipid và lipoprotein trong gan, bao gồm tăng TG, LDL và lipoprotein tỷ trọng rất thấp (VLDL) và giảm mức $\mathrm{HDL}-\mathrm{C}$.

4.2. Mối liên quan giữa RLLP máu với một số chỉ số lâm sàng và cận lâm sàng của đối tượng nghiên cứu. Trong nghiên cứu của chúng tôi ở bảng 4 , tỷ lệ bệnh nhân có RLLP máu ở nhóm bệnh nhân có BMI $\geq 23$ là $93,02 \%$ cao hơn so với nhóm có $\mathrm{BMI}<23$ là $81,25 \%$, sứ khác biệt có ý nghĩa thống kê với $\mathrm{p}<0,05$. Ớ nhóm bệnh nhân béo bụng tỷ lệ RLLP máu là 92,31\% cao hơn nhóm bệnh nhân không béo bụng là $81,35 \%$, sự khác biệt có ý nghĩa thống kê với $p<0,05$. Kết quả trên gần tương đương với nghiên cứu của Nguyễn Thị Hồng Thuỷ (2016) trên bệnh nhân cao tuổi tại Phú Yên: Có sự tương quan mức độ vừa giữa $\mathrm{TG}$, cholesterol và $L D L-C$ với các yếu tố $B M I_{2} V B$ do có $p<0,05$. Trong một nghiên của Nguyển Lân Việt đã chỉ ra rằng chỉ số khối cơ thể và vòng bụng chính là các yếu tố nguy cơ gây RLLP máu ở bệnh nhân THA. Nghiên cứu của Urvi Sharma và cộng sự (2013) cho thấy béo phì có liên quan đến tình trạng rối loạn lipid máu ở bệnh nhân tăng huyết áp[7]. Nghiên cứu của Francesco Spannella và cộng sự (2019) cũng cho thấy thừa cân theo chỉ số BMI và vòng bụng có liên quan đến tình trạng rối loạn lipid máu ở bệnh nhân tăng huyết áp [8]. Béo phì và hậu quả là đề kháng insulin là những yếu tố cơ bản chính trong cơ chế bệnh sinh của cả tăng huyết áp và rối loạn lipid máu. Có một mối liên hệ chặt chẽ giữa những rối loạn chuyển hóa này trong hội chứng chuyển hóa [2].

Tỷ lệ RLLP máu ở nhóm bệnh nhân có thời gian phát hiện THA $\geq 5$ năm là $91,14 \%$, còn ở nhóm có thời gian phát hiện $\mathrm{THA}<5$ năm là $82,19 \%$, sự khác biệt có ý nghĩa thống kê với $p$ $<0,05$. Nghiên cứu của Võ Như An cũng cho kết quả tương tự.

Trong nghiên cứu của chúng tôi 7, tỷ lệ RLLP máu ở nhóm bệnh nhân ít vận động thể lực là 92,86\% cao hơn ở nhóm bệnh nhân có vận động thể lực là $81,19 \%$, sự khác biệt có ý nghĩa thống kê với $p<0,05$. Kết quả ngiên cứu của Chu Hồng Thắng thấy rằng Cholesterol máu tăng cao hơn bình thường gặp nhiều nhất ở nhóm đối tượng ít vận động (69,9\%).

Trong nghiên cứu của chúng tôi thì nhóm bệnh nhân lạm dụng rượu có tỷ lệ RLLP máu là $93,75 \%$ cao hơn có ý nghĩa thổng kê so với nhóm bệnh nhân không lạm dụng rượu là $81,43 \%$ với $p<0,05$. Nghiên cứu của Nguyễn Lân Việt và cộng sự đã chỉ ra mối liên quan mật thiết giữa nghiện rượu, béo phì, rối loạn lipid máu và tăng huyết áp. Nghiên cứu của Urvi Sharma và cộng sự (2013) cho thấy lạm dụng rượu có liên quan đến tình trạng rối loạn lipid máu ở bệnh nhân tăng huyết áp [7].

\section{KẾT LUẬN}

- Tỷ lệ rối loạn lipid máu ở bệnh nhân cao tuổi tăng huyết áp là 88,0\%.

- Có mối liên quan giữa rối loạn lipid máu với tình trạng gan nhiếm mõ̃, chỉ số BMI, chỉ số vòng bụng, thời gian phát hiện tăng huyết áp, uống nhiều rượu và ít vận động thể lực.

- Chưa thấy mối liển quan giữa rối loạn lipid 
máu với nhóm tuổi ( $\geq 70$ tuổi so với 60 - 69 tuổi), giới, tiền sử gia đình bị rối loạn lipid máu.

\section{TÀI LIÊU THAM KHẢO}

1. Bô Y tế (2015), "Hướng dẫn chẩn đoán bênh và điều trị bệnh nội tiết và chuyển hóa," Nhà xuất bản Y hoc, tr. 255-275.

2. Ayoade O. G., Umoh I., Amadi C. (2020), "Dyslipidemia and Associated Risk Factors among Nigerians with Hypertension," Dubai Med. J., vol. 3, no. 4, pp. 155-161.

3. Chobanian A. V et al (2003), "Seventh report of the Joint National Committee on Prevention Detection, Evaluation, and Treatment of High Blood Pressure.," Hypertens. (Dallas, Tex. 1979) vol. 42, no. 6, pp. 1206-1252.

4. Ericsson S., Eriksson M., Vitols S., Einarsson K., Berglund L., Angelin B. (1991), "Influence of age on the metabolism of plasma low density lipoproteins in healthy males," J. Clin. Invest., vol. 87 , no. 2, pp. 591-596.
5. Fakhrul Alam L. C. (2021), "Dyslipidemia Associated with Hypertension Increases the Risks for Coronary Heart Disease: A Case-Control Study in a tertiary level hospital in Bangladesh," J. Med. Sci. Clin. Res., vol. 09.

6. Sanyal A. J. (2002), "AGA technical review on nonalcoholic fatty liver disease.," Gastroenterology, vol. 123 , no. 5, pp. 1705-1725.

7. Sharma U., Kishore J., Garg A., Anand T., Chakraborty M., Lali P. (2013), "Dyslipidemia and associated risk factors in a resettlement colony of Delhi.," J. Clin. Lipidol., vol. 7, no. 6, pp. 653-660.

8. Spannella F., Giulietti F., Di Pentima C. Sarzani R. (2019), "Prevalence and Control of Dyslipidemia in Patients Referred for High Blood Pressure: The Disregarded 'Double-Trouble' Lipid Profile in Overweight/Obese," Adv. Ther., vol. 36, no. 6, pp. 1426-143.

9. Wang $X$., Magkos F., Mittendorfer B. (2011), "Sex differences in lipid and lipoprotein metabolism: It's not just about sex hormones," J. Clin. Endocrinol. Metab., vol. 96, no. 4, pp. 885-893.

\section{ĐÁNH GIÁ MộT SỐ YẾU TỐ LIÊN QUAN KÍCH ĐộNG Ở BÊNNH NHÂN TÂM THẦN PHÂN LIÊTT}

\section{Nguyễn Đức Vượng ${ }^{2}$, Nguyễn Văn Tuấn ${ }^{2}$, Nguyễn Kim Việt ${ }^{1}$ \\ TO AGITATION IN PATIENTS WITH SCHIZOPHRENIA}

\section{TÓM TẮT}

Đặt vấn đề: Kích động là một tập hợp không cụ thể các hành vi không liên quan được đặc trưng do vận động hoặc hoạt động bằng lời nói quá mức, cáu kỉnh, bất hợp tác, bộc phát giọng nói, cử chỉ đe dọa và hành hung. Kích động xuất hiện trong nhiều bệnh cơ thể và tâm thần như tâm thần phân liệt, rối loạn cảm xúc lưỡng cực và sa sút trí tuê. Nghiên cứu về các yếu tố nguy cơ có thể giúp quản lỳ, phòng ngừa và điêu trị sớm kích động ở bênh nhân tâm thần phân liêt. Muc tiêu: Đánh giá một số yếu tố liên quan kích động ở bênh nhân tâm thần phân liêt. Phương pháp nghiên cứu: Nghiên cứu cắt ngang trên 83 bệnh nhân có kích động được chẩn đoán tâm thần phân liêt điều trị nội trú tại Bệnh viện Tâm Thần Hà Nội. Kết quả: Không tìm thấy mối liên quan giữa kích đông với giới tính trình độ học vấn và tình trạng nghể nghiệp. Có mố liên quan giữa kích động mức độ nặng với nhóm tuổi trẻ; sống ở nông thôn; với tiền sử gây hân; bỏ điều trị, tình trạng cưỡng ép nhập viện và triệu chứng dương tính của bệnh tâm thân phân liệt.

Tư khóa: kích động, tâm thần phẩn liệt.

\section{SUMMARY \\ ASSESSMENT OF SOME FACTORS RELATED}

${ }^{1}$ Trường Đại học Y Hà Nội

${ }^{2}$ Bệnh viện Tâm Thần Hà Nội

Chịu trách nhiệm chính: Nguyễn Đức Vượng

Email: ths.nguyenvuong@gmail.com

Ngày nhận bài: 10.8.2021

Ngày phản biên khoa hoc: 6.10 .2021

Ngày duyệt bài: 15.10.2021
Background: Agitation is a nonspecific set of unrelated behaviors, which characterized by excessive verbal or movement activity, irritability, noncooperation, vocal outbursts, threatening gestures, and aggression. Agitation is present in many physical and mental illnesses such as schizophrenia, bipolar affective disorder, and dementia. Research on risk factors can make usefully for the management, prevention, and early treatment of agitation in patients with schizophrenia. Objectives: Evaluation of some factors related to agitation in schizophrenia patients. Method: Cross-sectional study on 83 agitation patients with schizophrenia inpatient treatment at Hanoi Mental Hospital. Results: There is non association was found between agitation and gender, education level and occupational status. There is a relationship between severe agitation and young age group; live in the countryside; with a history of aggression; abandoned treatment, compulsive hospitalization, and positive symptoms of schizophrenia.

Keywords: agitation, schizophrenia.

\section{I. ĐĂT VẤN ĐỀ}

Theo một nghiên cứu cắt ngang đa trung tâm tại các đơn vị cấp cứu tâm thần ở Châu Âu, bệnh nhân tâm thần phân liệt chiếm tỷ lệ cơ bản, $32,8 \%$ - 43,9\% trong các cơn kích động tâm thần. Ở Trung Quốc, sàng lọc 1400 bệnh nhân mới nhập viện bị tâm thần phân liệt, tương ứng theo thang đánh giá, phát hiện 59,00\% - 